\title{
COLLEGE CAMPUS AS A ROLE MODEL FOR ENVIRONMENTAL CONSCIOUSNESS
}

\author{
Mohamed Rizwan Khan \\ Dept. of Zoology, Radhabai Kale Mahila Mahavidyalaya, Ahmednagar (M.S.) India. \\ *Corresponding Author: mail: rizwan_khan672@yahoo.com
}

\begin{abstract}
:
India is a young country. College is the place where this youth come to learn and spend lot of time. These students are the future and part of the society. As our planet earth faces many environmental issues, college is the best place for sensitization of students regarding environment. Students propagate this to their locality also. This paper deals with measures the college can adopts for ecofriendly campus and to become a role model for environmental consciousness like green audit, e governance, vermicompost plant, rainwater harvesting project, biogas plant, botanical garden, hydroponics, use of renewable energy, waste management, biodiversity posters \& environmental slogans, students projects based on environment and offering compulsory course on environmental education.
\end{abstract}

Key words: - Campus, College, Consciousness, Environment.

\section{INTRODUCTION:}

The human society is facing many environmental issues like pollution, population explosion, deforestation, resource depletion, loss of biodiversity etc. Sustainable development is a significant social, economic or environmental challenge for any country (Wynn Calder, 2003). The youth should get sensitive about environment. Education is one solution to solve environmental problem. The teaching and learning must begin to reflect environmental issues; there is an emerging consensus that institutions must also model sustainable practices (Erin Redman, 2013). Students take with them the green practices and approaches they were involved with at their institution (Will Toor, 2003). Environmental education becomes integral part in syllabus. National Assessment and Accreditation Council an autonomous institution of the University Grants Commission play important role in periodic assessment and accreditation of higher education institutions also gives importance to environment consciousness and sustainability. In Criteria 7 Institutional Values and Best Practices of NAAC manual for the college, environmental consciousness and sustainability is incorporated which includes metrics regarding use of alternate energy sources, management of waste, water conservation facilities, green campus initiatives and quality audits on environment. Eco friendly college means "environmental sustainability within the college". Eco friendly college campus mainly focuses on the efficient uses of energy and water, minimize waste generation or pollution and also economic efficiency. Eco friendly college focuses on the reduction of the emissions of green house gases, more use of renewable energy, rainwater harvesting, encourages staff and student for environmental issues, to have significant environmental impacts. Following measures and activities can be adopted by college to make campus ecofriendly.

Vermicompost Plant: Construction of vermicompost pit for the waste from gardens 
and office can be converted to vermicompost which is used as compost for plants in campus.

Rainwater harvesting: Collection of rain water in ponds and using it for laboratory purpose.

Biogas plant: Construction of biogas plant for the biodegradable waste from hostel can be converted to biogas.

Solar Panels: Installation of solar panels at prominent places to utilize renewable solar energy for laboratory work.

Botanical Garden: Maintenance of botanical garden for aesthetic purpose and to attract insects specially butterflies which help in biodiversity study.

Green campus: Plantation programme for green campus so that more carbon dioxide can be fixed and tree attract many birds for their nesting and green initiatives like observation of no vehicle day, environment days etc.

E-waste management: E-waste produced by Information Technology Department is managed by recycling and by doing annual maintenance contract.

Green audit: Green audit of the college should be done regularly.

\section{Biodiversity Posters \& Environmental}

Slogans: Local Biodiversity posters and environmental slogans at prominent places in campus should be displayed which aware students and staff.

Dust bin: Separate dust bin for liquid and solid waste should be placed and properly used.

Hydroponics: Plants can be cultivated in mineral rich water without soil.
E governance: Use of mobile applications, SMS and email for admission and governance.

LED and CFL: To decrease the energy consumption use of CFL and LED should be promoted, five star electronic appliances can be preferred and students and staff should be promoted to switch off appliances after use.

Organization of environmental awareness activities like poster presentation, environmental related day celebration, plays, seminar, conference etc. and involvement of students and staff.

To frame various college level committees related to environment like water management committee, green audit committee, energy conservation committee, waste recycling committee.

\section{CONCLUSION:}

College is the place where students spend more time. These young students are the future of any nation. Awareness of these students regarding environmental issues is very important. Eco friendly college campus can be a very good model to learn and sanitizes the students regarding environment that can be passed to society also. For that, college can establish eco friendly college committee to look and implement eco-friendly measures

\section{REFERENCES:}

Erin Redman, (2013): Advancing educational pedagogy for sustainability: Developing and implementing programs to transform behaviors, International Journal of Environmental and Science education, Vol. 8, No. 1, January, 1-34.

Wynn Calder and Richard M. Clugston, 2003, Progress Toward Sustainability in Higher Education, ELR News \& Analysis Environmental Law Institute ${ }^{\circledR}$, 
Washington, DC. Reprinted with permission from $\quad E L R \circledast$, http:/ /www.eli.org, 1-800-433-5120.

Will Toor, (2003): “The Road Less Traveled: Sustainable Transportation for Campus,"
Planning for Higher Education, MarchMay 137-140.

http://www.naac.gov.in/images/docs/Manual s/Affiliated_Constituent-UG-PG-Colleges04 Feb2020.pdf 